UDK 616.31-053.9

ORIGINAL ARTICLE

\section{Life Quality Of Patients Treated With Fixed And Mobile Dentures}

\begin{abstract}
Introduction. One of the most important objectives of an oral health care is helping patients in the effort to reach a high level of satisfaction with their mouth cavity with or without teeth.

Patients and Methods. The paper aims to establish the connection between the satisfaction of patients treated with fixed and mobile dentures on one side, and oral health, quality of life and psychological characteristics of patients on the other. The research was conducted as a prospective study with 320 patients separated into three groups - group I (patients treated with fixed dentures), group II (patients treated with mobile dentures), and group III (patients treated with both mobile and fixed dentures). The oral related life quality was observed within five dimensions: anamneses data, symptoms of ill-functioning of stomatogenic system (chewing and speech), dental status - extraoral, dental status - intraoral and dental abilities.
\end{abstract}

Conclusion. The linear regression model was adopted for the purpose of analysis of target markers and oral health determination. The research showed that oral-related quality of life in patients treated with fixed and mobile dentures was most affected by intraoral clinical features, psychological characteristics, and the type of denture, along with a whole range of minor factors (age, timing of denture treatment after the teeth loss, period of denture usage, order of denture implantation, mouth cavity hygiene, diet).

Key words: quality of oral health, dental abilities, oral health features

DOI: 10.7251/SMD1402058G

(Scr Med 2014:45:62-66)

\section{Sanja Gnjato}

Faculty of Medicine, University of Banjaluka

\section{Contact:}

Sanja Gnjato

University of Banja Luka

Faculty of Medicine,

Save Mrkalja 14

$780 o$ o Banja Luka

tel. +38751234113

e-mail: sanja.gnjato@gmail.com

Submitted: September 2nd, 2014 Accepted: October 23rd, 2014

\section{Introduction}

One of the most important objectives of an oral health care is helping patients in the effort to reach a high level of satisfaction with their mouth cavity with or without teeth. ${ }^{1,2}$ The research of oral health and its impact on patients' life quality has largely advanced in late 20th and early 21st century.3,4 In this regard, only few studies have proved interdependence among the psychological profile, oral status, denture treatments, and a patient's quality of life. Thereby, the aim was to estimate specific forms of social functions, behavior, and effects of patient's oral health satisfaction, all of which are expressed via aesthetics, performance, and functions. ${ }^{5}$

Strauss and Hunt 6 inferred that dental disease and consequences of oral treatments affected patients' ability to live and enjoy life, make social connections, be positive about their jobs, and stay positive. Oral health satisfaction can be measured by using different indicators such as taste, pain, speech, aesthetics, etc. All these affect the quality of life. ${ }^{7}$ 
As he studied the effects of oral health on denture-treated patients' daily performances, Wostmann ${ }^{8}$ concluded that the quality of life greatly improves upon the denture treatments. The improvement referred to appearance, functions, comfort, pain relief, and eating disorder. World Health Organization initialized these issues within the context of development policy in 1980 s. $^{9}$

Our target study resulted in an original model for the estimation of oral-related quality of life. The research covered five dimensions of dental health quality: anamneses data, symptoms of ill-functioning stomatogenic system (chewing and speech), dental status - extraoral, dental status - intraoral and dental abilities. Eventually, it confirmed our initial hypothesis on the interdependence between the quality of life on one side and psychological profile and type of denture on the other.

Having tested the model of oral-related quality of life on patients treated with fixed and mobile dentures under the clinical conditions, we assumed that the improvement of patients' life quality should be managed in a responsible and institutional manner.

\section{Methods and materials}

The research was conducted at the Institute of stomatology in Banja Luka and it covered 360 patients singled out in three groups: group I (patients treated with fixed dentures), group II (patients treated with mobile dentures), and group III (patients treated with both mobile and fixed dentures). Each group had the identical number of patients and equal age and sex structure. All denture treatments were performed in order to establish complete mastication and other oral functions. For the purpose of the research, a special dental record was designed and the data were entered for each individual patient. The dental record included the following information: the general information with 10 markers, anamneses data with 16 markers, symptoms of ill-functioning oral system (chewing and speech) with 6 markers, clinical examination - extraoral dental status with 8 markers, clinical examination - intraoral status with 12 markers, additional clinical procedures with 5 markers, scanning of TM joints with 3 markers and a questionnaire of dental abilities with the total of 36 markers grouped in five dimensions (appearance, pain, comfort, satisfaction, and eating limitations). Each questionnaire provided three entry options: positive, neutral, and negative.

Patients had been observed for 17 months ranging from May 2012 to September 2013. The clinical dental status, dental abilities, and psychological status of each patient were estimated three times - at the beginning of the research, six months afterwards, and at the end.

The statistical methods of the research were as follows ${ }^{10}$ : statistical methodology applied at the research result display covered four research phases - descriptive statistics, statistical analysis, inferential statistics, and the research deduction and decision making. Statistical methods were applied via relevant statistical standards (ISO 10576-1: Statistical methods - Guidelines for the evaluation of conformity with specified requirements - Part 1: General principles; ISO TS 21747: Statistical methods Process performance and capability for measured quality characteristics; ISO 11453: Statistical interpretation of data - Tests and confidence intervals relating to proportions; ASQ Z1.4: Sampling procedures and tables for inspection by attributes) and the standard software was used (Microsoft Office: Excel 2010, www.microsoft.com/Office365).

Modeling of oral-related quality of life: Dental health quality was observed through five dimensions - anamneses data, symptoms of ill-functioning stomatogenic system (chewing and speech), dental status - extra-oral, dental status - intraoral, and dental abilities. The quality of oral health was modeled as the linear regressive model with hierarchical weight coefficient, assuming that the adequate regressive residues were equal to zero. Thus, the index of dental health quality was presented by using the general regression equation:

$$
\mathrm{I}_{K D Z}=K_{A} * I_{A}+K_{S} * I_{S}+K_{D S E} * I_{D S E}+K_{D S I} I_{D S I}+K_{D S} * I_{D S}
$$

in which $\mathrm{I}_{\mathrm{KDZ}}$ is the dependent variable, i.e. the index (score) of dental health quality; $\mathrm{K}_{\mathrm{A}}$ is regression coefficient, i.e. the hierarchical weight coefficient of the dental health quality dimension referred to as "anamneses", $\mathrm{I}_{\mathrm{A}}$ is the independent variable, i.e. the index (score) of the dental health quality dimension referred to as "anamneses", $\mathrm{K}_{\mathrm{s}}$ is the regression coefficient, i.e. the hierarchical weight coefficient of the dental health quality dimension referred to as "symptoms", $I_{S}$ is the independent variable, i.e. the index (score) of the dental health quality dimension referred to as "symptoms", $\mathrm{K}_{\mathrm{DSE}}$ is the regression coefficient, i.e. the hierarchical weight coefficient of the dental health quality dimension referred to as "dental status extra-oral", $I_{D S E}$ is the independent variable, i.e. the index (score) of the dental health quality dimension referred to as "dental status extra-oral", $\mathrm{K}_{\mathrm{DSI}}$ is the regression coefficient, i.e. the hierarchical weight coefficient of the dental health quality dimension referred to as "dental status intraoral", $\mathrm{I}_{\mathrm{DSI}}$ is the independent variable, i.e. the index (score) of the dental health quality dimension referred to as "dental status intraoral", $\mathrm{K}_{\mathrm{DS}}$ is the regression coefficient, i.e. the hierarchical weight coefficient of the dental health quality dimension referred to as "dental abilities" and $\mathrm{I}_{\mathrm{DS}}$ is the independent variable, i.e. the index (score) of the dental health quality dimension referred to as "dental abilities".

In order to calculate the oral health quality (index), for each observed dimension and element within it, the following was set: relevance rank - hierarchical weight coefficient 
and contribution (positive - the more the better, negative - the less the worse).

\section{Results}

The clinical research determined the dental health quality (index) with the chosen sample of 360 patients treated with fixed and mobile dentures. The result was that the oral-related life quality can be divided into five attributive categories depending on the total number of index score obtained by calculating index of dental health quality for each patient: excellent (score $<38,0$ ), good (score $38,0-51,0$ ), satisfactory (score 51,1-65,0), unsatisfactory (score 65,1-79,0) and poor (score $(>79,0)$.

The effect of individual dimensions of dental abilities (as a psychological category) was observed separately. We shall display the research results showing impact of five dimensions of dental abilities (appearance, pain, conformity, satisfaction, eating limitations). Each dimension of dental abilities was divided into five attributive categories as shown in pictures.

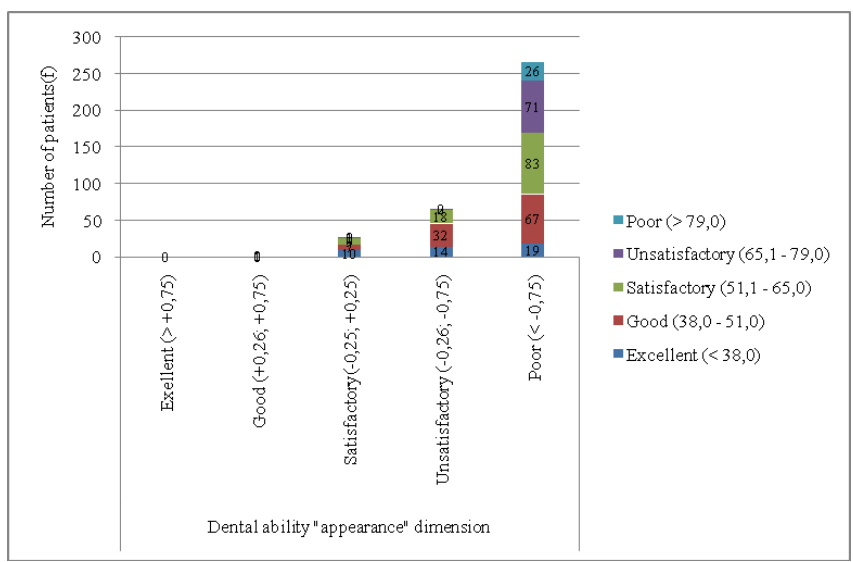

Picture 1. Distribution of patients and their oral-related life quality from the aspect of the dental ability dimension referred to as "appearance"

Picture 1. displays the effect of the dental ability dimension termed "appearance" on the patients' oral-related quality of life, i.e. it shows how patients' satisfaction with appearance, color, and teeth distribution affect their quality of life. The aesthetic appearance of patients is very important, and it provides the patients with confidence along with the adequate therapy, teeth settings, color choice, and shape and size of the teeth. Testing proved that there was a statistically relevant difference between oral-related quality of life and the dental ability dimension referred to as "appearance" $(\mathrm{p}=0,0029)$.

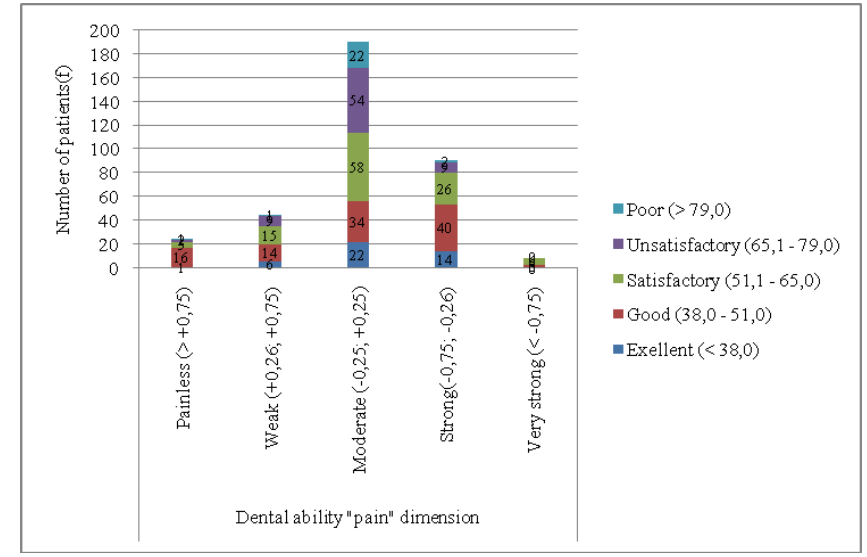

Picture 2. Distribution of patients and their oral-related life quality from the aspect of the dental ability dimension referred to as "pain"

Picture 2. displays the effect of the dental ability dimension referred to as "pain" on the patients' oral-related quality of life, i.e. it shows how patients' type of pain, intensity of pain (small, moderate, strong, very strong),pain duration, spontaneous or provoked pain due to physical-chemical agents, hot food, bruxism, trauma, diet, and inflammation affect their quality of life. Testing proved that there was a statistically relevant difference between oral-related quality of life and the dental ability dimension referred to as "pain" $(\mathrm{p}=\mathrm{o}, 0000)$.

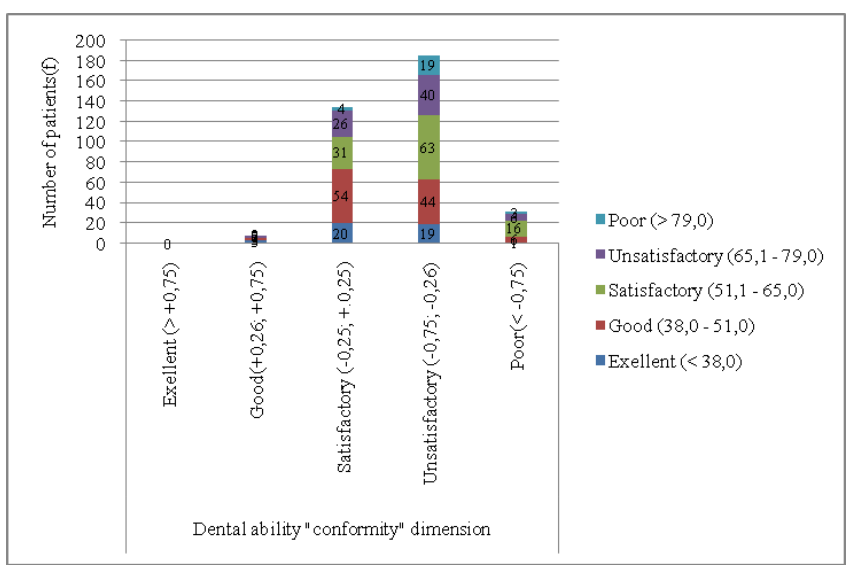

Picture 3. Distribution of patients and their oral-related life quality from the aspect of the dental ability dimension referred to as "conformity"

Picture 3. displays the effect of the dental ability dimension referred to as "conformity" on the patients' oral-related quality of life, i.e. it shows how patient's oral-related life quality is affected by teeth and gum issues. The lack of teeth, tooth migration towards empty space within gums, change of tooth position, etc. result in IKP ratio disturbance. Patients are not satisfied with the existing condition within their mouth cavity as it results in no "conformity" while eating and drinking. Testing proved 
that there was no statistically relevant difference between oral-related quality of life and the dental ability dimension referred to as "conformity" ( $\mathrm{p}=\mathrm{0}, \mathrm{o633})$.

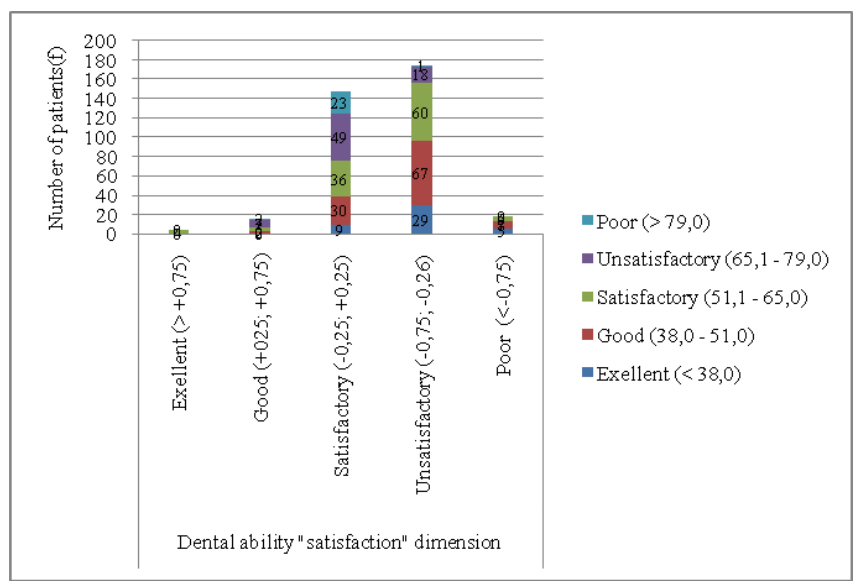

Picture 4. Distribution of patients and their oral-related life quality from the aspect of the dental ability dimension referred to as "satisfaction"

Picture 4. displays the effect of the dental ability dimension referred to as "satisfaction" on the patients' oral-related quality of life, i.e. it shows how the patients' dental quality of life is affected by teeth appearance and ability to eat and speak from the aspect of their working capacities, teeth appearance and ability to eat and speak from the aspect of social and emotional life, pain from the aspect of social and emotional life, appearance and self-confidence, appearance and laughter, working abilities, stress, and dental pain, sleeping and dental pain. Testing proved that there was a statistically relevant difference between oral-related quality of life and the dental ability dimension referred to as "satisfaction" ( $\mathrm{p}=\mathrm{0}, 0000)$.

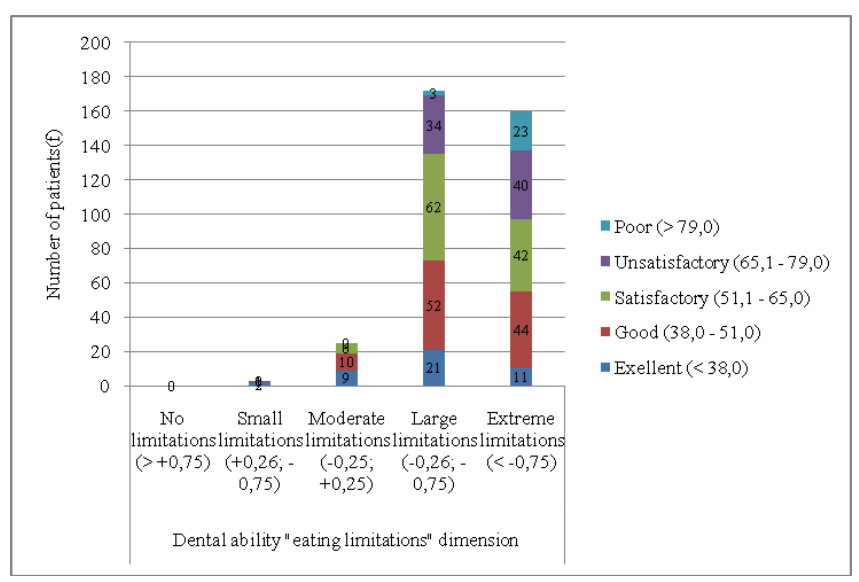

Picture 5. Distribution of patients and their oral-related life quality from the aspect of the dental ability dimension referred to as"eating limitations"
Picture 5. displays the effect of the dental ability dimension referred to as"eating limitations" on the patients' oralrelated quality of life, i.e. it shows how oral-related life quality affects the ability to chew and eat. Chewing and mastication depend on the IKP stability, the number of central contacts in occlusal position, lateral movements, absence of occlusal disturbance, pain in TM joints and masticatory muscles, and denture quality. Patients experiencing disturbed occlusion have to change the type of food and the food preparation process. Testing proved that there was no statistically relevant difference between oral-related quality of life and the dental ability dimension referred to as "eating limitations" $(\mathrm{p}=\mathrm{0}, \mathrm{0633})$.

\section{Discussion}

Researches have shown that different levels of oral health have a various impact on satisfaction of patients treated with fixed and mobile dentures. Poor bibliography indicates that patients' satisfaction with their oral status, including prosthetics, is in connection with the personality profile, which further implies the necessity for additional studies within the field. ${ }^{11}$ Different levels of oral status have different influence on patients' everyday life. In order to achieve a patients' quality of life and satisfaction, it is necessary to conduct treatments and obtain a clinical status regardless of the dental status.

Statistical analysis of the patients' research markers in comparisons with the oral-related life quality showed that there was a statistically relevant difference between dental health quality and dimensions referred to as „appearance“ ( $p=0,0029)$, "pain" ( $p=0,0000)$ and "satisfaction" $(\mathrm{p}=0,0000)$ and that there was no statistically relevant difference with the dimensions referred to as "conformity“ $(\mathrm{p}=0$, o633) and „eating limitations“ $(\mathrm{p}=0,0633)$. These results may be compared with those of Kressin's ${ }^{12}$ who concluded that the measurement of personal perception of one's oral status may be useful for the patient-doctor communication.

\section{Conclusion}

The quality of dental health (index) was modeled and tested within a clinical research covering five attributive markers: excellent, good, satisfactory, unsatisfactory, and poor.

Out of 49 analyzed markers of dental health, 32 markers showed high statistical relevance, 4 were statistically relevant, and 7 markers had no statistically relevant impact on the dental health quality index.

It was proved that all the research markers which had statistically relevant difference in comparison with the dental health quality negatively affected dental abilities of the patients, and the patients grouped in a higher dental health category suffered a poorer impact of negative markers. 


\section{Reference}

1. Mahmoud K, Al.O, Jumana K. Relationship between Oral HealthRelated Quality of Life, Satisfaction and Personality in Patients with Prosthetic Rehabilitations, Journal of Prosthodontics, 19, The American College of Prosthodontists. 2010.

2. Džambas L. D, Bokor-Bratić M, Džambas B, Selaković S, Hrvaćanin S. O, Jefić B. Aktivan i kvalitetan život starih osoba rehabilitovanih totalnim zubnim protezama.Gerontologija. 2002; 30 (1):191-195.

3. Bae KH, Kim C, Paik DI, Kim JB. A comparison of oral health related quality of life between complete and partial removable denture-wearing older adults in Korea, Journal of Oral Rehabilitation, 2006; 33, 5 .

4. Bae KH, Kim HD, Jung SH, Park DY, Kim JB, Paik DI, Chung SC. Validation of the Korean version of the oral health impact profile among the Korean elderly, Community Dentistry and Oral Epidemiology, 2007; 35, 1.4

5. Leao A, Sheiham A. The development of a socio-dental measure of Dental Impacts on Daily Living. Community Dental Health. 1996;13:22-26. [PubMed]
6. Strauss R, Hunt R. Understanding the value of teeth to older adults: influences on the quality of life. J Am Dent Ass. 1993;124:105-110. [PubMed]

7. Adulyanon S, Sheiham A, Oral Impacts on Daily Performances. In Measuring Oral Health and Quality of Life, Edited by Slade G. Chapel Hill, University of North Carolina. Dental Ecology. 1997.

8. Wostmann B. Dental Impact on Daily Living and Removable Partial Dentures, Justus-Liebig University, Giessen, Germany. 2007.

9. World Health Organization (WHO) community periodontal index of treatment needs (CPITN). hit Dent J 1982; 32:281 -291.

10. Tanjga R. Statistika u medicini, Medicinski fakultet, Banja Luka, 2004.

11. Christopher D Lynch, Edward Lynch. Relationshipbetween impacts of removable prosthodontic rehabilitation on daily living, satisfaction and personality profiles, Journal of Dentistry, 2014; $42,3,366$.

12. Kressin NR. Associations among different assessments of oral healthoutcomes, J Dent 1 due 1996; 60:501 -507.

\section{Kvalitet života pacijenata saniranih fiksnim i mobilnim stomatoprotetičkim radovima}

\section{SAŽETAK}

Uvod. Jedan od najvažnijih ciljeva stomatološke njege i zaštite je pomoć pacijentima u nastojanju da dostignu visok nivo zadovoljstva stanjem usne šupljine sa ili bez zuba.

Ispitanici i metode. Utvrditi vezu između zadovoljstva pacijenata saniranih fiksnim i mobilnim stomaprotetičkim radovima, s jedne te oralnog zdravlja, kvaliteta života i psiholoških karakteristika pacijenata, s druge strane. Istraživanje je provedeno kao prospektivna studija, na uzorku od 320 pacijenata, svrstanih u tri brojčano jednake grupe: I grupa, pacijenti sanirani fiksnim stomatoprotetičkim radovima; II grupa, pacijenti sanirani mobilnim stomatoprotetičkim radovima; III grupa, pacijenti sanirani mobilnim i fiksnim stomatoprotetičkim radovima. Kvalitet dentalnog zdravlja posmatran je kroz 5 dimenzija: anamnestički podaci; simptomi poremećaja funkcija stomatogenog sistema (žvakanje i govor); dentalni status - ekstraoralni; dentalni status intraoralni; dentalne sposobnosti.

Zaključak. Za analizu istraživačkih obilježja i određivanje kvaliteta dentalnog zdravlja usvojen je linearni regresioni model sa hijerarhijskim težinskim koeficijentima. Istraživnje je pokazalo da na dentalni kvalitet života pacijenata saniranih fiksnim i mobilnim stomatoprotetičkim radovima najveći uticaj imaju intraoralna klinička slika, psihološke karakteristike i vrsta stomatoprotetičke nadoknade, te niz drugih, relativno manje uticajnih faktora (dob pacijenta, vrijeme sanacije nakon gubitka zuba, period korištenja nadoknade, redoslijed nadoknade, nivo higijene usne duplje, način ishrane).

Ključne riječi: kvalitet dentalnog zdravlja, dentalne sposobnosti, dimenzije dentalnog zdravlja 